PRACE NAUKOWE UNIWERSYTETU EKONOMICZNEGO WE WROCLAWIU

Nauki ekonomiczne w XXI wieku - wyzwania, dylematy, perspektywy

ISSN 1899-3192

Ekonomia, finanse, nauki o zarządzaniu

e-ISSN 2392-0041

\title{
Agnieszka Sokołowska-Durkalec
}

Uniwersytet Ekonomiczny we Wrocławiu

e-mail: agnieszka.sokolowska@ue.wroc.pl

\section{IDENTYFIKACJA WYBRANYCH PROBLEMÓW \\ DOTYCZĄCYCH IMPLEMENTACJI \\ KONCEPCJI SPOLECZNEJ ODPOWIEDZIALNOŚCI - PERSPEKTYWA MAŁEGO PRZEDSIĘBIORSTWA}

\section{IDENTIFICATION OF SELECTED PROBLEMS \\ RELATING TO IMPLEMENTATION \\ OF SOCIAL RESPONSIBILITY CONCEPTION - PERSPECTIVE OF SMALL ENTERPRISE}

DOI: $10.15611 /$ pn.2017.499.24

JEL Classification: M14

Streszczenie: Rozważania przedstawione w artykule są kontynuacją wielowymiarowych badań literaturowych i empirycznych dotyczących identyfikacji, oceny i kierunków doskonalenia społecznej odpowiedzialności małego przedsiębiorstwa z perspektywy zarządzania jej obszarami. Dotykają wymiaru doskonalenia społecznej odpowiedzialności i są doniesieniem z dalszej eksploracji problematyki (wyników badań empirycznych), a dokładnie obserwacji wdrożeń założeń i stosowania wybranych instrumentów koncepcji w małych przedsiębiorstwach. Celem artykułu jest identyfikacja wybranych problemów dotyczących implementacji założeń koncepcji społecznej odpowiedzialności w małym przedsiębiorstwie. W części teoretycznej zaprezentowano główne założenia i specyfikę procedury implementacji koncepcji społecznej odpowiedzialności w małym przedsiębiorstwie, w empirycznej natomiast przedstawiono wybrane wnioski z analizy studiów przypadków małych przedsiębiorstw, w których trwa proces przedmiotowej implementacji. Na tej podstawie zidentyfikowano wybrane trudności związane z wdrożeniem koncepcji.

Słowa kluczowe: społeczna odpowiedzialność, małe przedsiębiorstwo, implementacja koncepcji.

Summary: The article, discussing both theoretical and empirical aspects of the research problem, presents key assumptions of social responsibility in small enterprise, together with proceeding and problems of their implementation, as well as conclusions of s case studies analysis of small enterprise, wherein runs implementation process.

Keywords: social responsibility, small enterpise, implementation of conception. 


\section{Wstęp}

Nasycenie literatury przedmiotu rozpatrywaniem problematyki społecznej odpowiedzialności przedsiębiorstwa argumentacją na rzecz jej stosowania oraz prezentacją teoretyczno-empirycznych dociekań z tego obszaru dedykowanych głównie dużym i średnim przedsiębiorstwom oraz innym organizacjom (urzędom, uniwersytetom itd.) stwarza potrzebę zapełnienia luki opracowań poświęconych małym przedsiębiorstwom, zwłaszcza realizacji w nich narzędziowej warstwy koncepcji.

Okazuje się, iż małe przedsiębiorstwa wykazują określoną aktywność w wielu obszarach działalności zaliczanych do społecznie odpowiedzialnych. Tym samym w celu zwiększania ich efektywności w tym zakresie oraz dążenia do bycia przedsiębiorstwem społecznie odpowiedzialnym istotne staje się rozpoznanie procedury implementacji założeń i instrumentarium koncepcji społecznej odpowiedzialności do warunków funkcjonowania małego przedsiębiorstwa. Dlatego ważne wydaje się poszukiwanie odpowiedzi na pytania, jakie są specyficzne cechy procedury implementacji koncepcji społecznej odpowiedzialności w małym przedsiębiorstwie oraz jakie można zidentyfikować problemy/trudności we wdrażaniu przedmiotowej koncepcji.

Rozważania przedstawione $\mathrm{w}$ artykule są kontynuacją wielowymiarowych badań literaturowych i empirycznych dotyczących identyfikacji, oceny i kierunków doskonalenia społecznej odpowiedzialności małego przedsiębiorstwa z perspektywy zarządzania jej obszarami. Dotykają wymiaru doskonalenia społecznej odpowiedzialności i są doniesieniem z dalszej eksploracji problematyki (wyników badań empirycznych), a dokładnie obserwacji wdrożeń założeń i stosowania wybranych instrumentów koncepcji w małych przedsiębiorstwach. Artykuł jest kontynuacją problematyki zawartej $\mathrm{w}$ artykule autorki pt.: Uwarunkowania implementacji założeń koncepcji społecznej odpowiedzialności w malym przedsiębiorstwie [Sokołowska 2016, s. 351-360].

Celem artykułu jest identyfikacja wybranych problemów dotyczących implementacji założeń koncepcji społecznej odpowiedzialności w małym przedsiębiorstwie. W części teoretycznej zaprezentowano główne założenia i specyfikę procedury implementacji koncepcji społecznej odpowiedzialności w małym przedsiębiorstwie, w empirycznej natomiast przedstawiono wybrane wnioski z analizy studiów przypadków małych przedsiębiorstw ${ }^{1}$, w których trwa proces przedmiotowej implementacji. Na tej podstawie zidentyfikowano wybrane trudności związane $\mathrm{z}$ wdrożeniem koncepcji.

\footnotetext{
${ }^{1}$ Ze względu na ograniczenia objętościowe artykułu przedstawiono w nim jedynie wybrane zagadnienia związane z kluczowymi, zidentyfikowanymi problemami implementacji koncepcji. Tym samym zrezygnowano z rozbudowanego opisu procesu badawczego oraz prezentacji szczegółowych wyników badań empirycznych (poszczególnych studiów przypadków) na rzecz syntetycznych, niepublikowanych w takiej formie i ujęciu wniosków poświęconych przedmiotowej problematyce.
} 


\section{Krótka charakterystyka społecznej odpowiedzialności przedsiębiorstwa}

W artykule przyjęto, iż społeczna odpowiedzialność to ekonomiczne, prawne, etyczne oraz filantropijne zobowiązanie przedsiębiorstwa względem wewnętrznych i zewnętrznych grup społecznych (i jednostek); ponadto może ona być przedmiotem celowego, racjonalnego i zinstytucjonalizowanego działania, które może stać się źródłem przewagi konkurencyjnej [Sokołowska 2013]. Wielowymiarowość i interdyscyplinarność pojęcia „społeczna odpowiedzialność” skłania do przyjęcia tak kompleksowego ujęcia, które łączy najpowszechniejsze w literaturze przedmiotu perspektywy jej rozumienia: ekonomiczną [Friedman 1970], etyczno-filozoficzną [Kung 1999, s. 386], uwypuklającą społeczną reakcję przedsiębiorstwa w kontekście relacji z interesariuszami [Carroll 1999, s. 268-295; Freeman, Philips 2002, s. 331-349] oraz normatywną wraz z wzorcami i mechanizmami ułatwiającymi społecznie odpowiedzialne działanie [Garriga, Mele 2004, s.52; Madueño i in. 2016]. Absolutnie fundamentalną podstawą społecznej odpowiedzialności jest wielowymiarowa odpowiedzialność (indywidualna, zespołowa, organizacyjna i międzyorganizacyjna) promieniująca na wszystkie obszary działalności przedsiębiorstwa i skutkująca odpowiadaniem - w ramach określonej kondycji i kontekstu sytuacyjnego - na oczekiwania interesariuszy.

Kontinuum rozważań nad społeczną odpowiedzialnością zmierza w kierunku uporządkowania i uchwycenia skomplikowanej społecznej „materii” i utrwalenia miejsca $\mathrm{w}$ zbiorze problematyk ważkich dla współczesnego zarządzania przedsiębiorstwem. Dlatego można mówić o koncepcji społecznej odpowiedzialności, na którą składają się warstwa zarówno ideowa wraz z zestawem założeń ją konstytuujących, jak i narzędziowa, zasobna w metody, techniki i narzędzia zarządzania. W warstwie ideowej można przyjąć wybrane zasady/standardy wypracowane przez międzynarodowe instytucje. Mowa tu o zasadach Okrągłego Stołu z Caux oraz zasadach Global Compact i Sullivana, które określają sposób postępowania związany $\mathrm{z}$ budowaniem zaufania w biznesie, albo przyjąć uniwersalny system etycznych wartości. Natomiast warstwa narzędziowa koncepcji wymaga podjęcia decyzji o zarządzaniu sformalizowanym (przy wykorzystaniu i adaptacji wytycznych międzynarodowych standardów normalizacji i oceny, takich jak m.in.: SA 8000, AA1000, ISO 26000) lub niesformalizowanym przy wykorzystaniu metod i narzędzi zapożyczonych z pokrewnych koncepcji, takich jak np.: zarządzanie zasobami ludzkimi, zarządzanie marketingowe, logistyczne itd. Proces zarządzania można opisać na zbiorze sekwencyjnych etapów, takich jak: identyfikowanie obszarów i podmiotów społecznej odpowiedzialności, planowanie, organizowanie, kształtowanie i kontrolowanie społecznej odpowiedzialności (por. [Sokołowska 2013, s. 138-139]). Efektem realizacji procesu są wymierne osiągnięcia wynikające $\mathrm{z}$ odpowiedzialnego funkcjonowania przedsiębiorstwa uzyskanego przez odpowiedzialne zarządzanie nim. Korzyści związane z wdrożeniem zasad społecznej odpowiedzialności związane są ze 
spójnością jej implementacji, realizacją, kontrolowaniem i ciągłym doskonaleniem [Sokołowska 2016, s. 354]. W tym kontekście istotne jest ustalenie specyficznych relacji między zbiorem zasad a ich przetransponowaniem na język praktyki, ważna jest też identyfikacja uwarunkowań (kontekstu sytuacyjnego) oraz mogących pojawić się trudności.

\section{Specyfika procedury implementacji koncepcji społecznej odpowiedzialności w małym przedsiębiorstwie}

Powodzenie efektywnej realizacji koncepcji społecznej odpowiedzialności uzależniona jest od wielu czynników; jednym z nich jest wielkość przedsiębiorstwa i wynikająca z niej specyfika. Charakterystyczne cechy małego przedsiębiorstwa mogą mieć wpływ na realizację koncepcji. Poprzez dostrzeżenie istoty i wagi działania firmy w sposób odpowiedzialny i przejrzysty małe przedsiębiorstwo może odnieść wiele korzyści, zdobywając zaufanie swoich kluczowych podmiotów w postaci: pracowników, klientów, społeczności lokalnej itd. Centralną postacią i decydentem (połączenie funkcji właściciela i menedżera²) w przedsiębiorstwie jest właściciel; to od jego wiedzy, zachowania i przekonania o słuszności wprowadzania zmian zależy powodzenie realizacji koncepcji; to on przekazuje wartości interesariuszom i je instytucjonalizuje. Właściciele małych firm winni wykorzystać fakt, że przebieg procesów społecznych w tej grupie przedsiębiorstw determinują najczęściej osobiste kontakty, które mogą zaowocować stosunkami opartymi na zaufaniu i twórczej współpracy. Zwinność (elastyczność, dynamizm i otwartość) małego przedsiębiorstwa stwarza warunki dla uznawania ważności procesów społecznych i związanych z nimi: przepływem informacji, zarządzania wiedzą, kapitałem intelektualnym i społecznym, a także dla kształtowania zrównoważonej kultury organizacyjnej opartej na zaufaniu i dialogu.

Bliskość rynku, na jakim działa małe przedsiębiorstwo, oznacza możliwość bardzo bliskich kontaktów z partnerami zewnętrznymi. Współpraca z klientami, dostawcami itd. bazuje często na osobistych kontaktach i wykracza poza formalne relacje. Małe przedsiębiorstwo może uzyskać dominację nad swoimi rywalami poprzez odpowiedzialne i przejrzyste działanie we wszystkich wymiarach, konkurując nie tylko z przedsiębiorstwami ze swojej grupy wielkościowej, ale także z przedsiębiorstwami dużymi o ugruntowanej pozycji. Specyficzne cechy wynikające $\mathrm{z}$ istoty prowadzenia działalności gospodarczej niewielkich rozmiarów wyznaczają także cechy obszarów (zakresu obszarów: ekonomicznego, prawnego, etycznego i filantropijnego) podmiotów społecznej odpowiedzialności (w znaczeniu ich celów, oczekiwań, zakresu relacji z przedsiębiorstwem), które nie będą takie same jak w przypadku

\footnotetext{
${ }^{2} \mathrm{~W}$ większych małych przedsiębiorstwach wraz z rozwojem działalności naturalne staje się oddzielenie tych funkcji, wówczas istotne - w kontekście społecznej odpowiedzialności - stają się dwukierunkowe relacje na linii: właściciel-menedżer, menedżer-pracownicy.
} 
dużych przedsiębiorstw. Podobnie odmienna będzie realizacja poszczególnych elementów procesu zarząadzania społeczną odpowiedzialnością.

Dlatego zestawienie specyfiki społecznej odpowiedzialności oraz działalności małego przedsiębiorstwa wymaga zaproponowania kilku kluczowych kroków w implementacji koncepcji. Wydaje się, iż można sformułować następujące założenia:

1. Właściciel przedsiębiorstwa, mając siłę decyzyjną i sprawczą, chcąc efektywnie zaimplementować założenia koncepcji, powinien zapoznać się z jej zasadami $i$ instrumentarium. Istotna jest także gotowość do zmian i przede wszystkim wiedza o korzyściach i stratach wynikających z przedmiotowych działań oraz analiza przykładów dobrych i złych praktyk. Zgromadzony kapitał wiedzy przedsiębiorcy o społecznej odpowiedzialności (zarówno jej przejawach, jak i osiągania poszczególnych stopni dojrzałości) osadzony w uświadomionych, szczegółowo zinterpretowanych cechach działalności małego przedsiębiorstwa może skutkować podjęciem decyzji o wdrożeniu koncepcji, a tym samym zainicjowaniu konkretnych, społecznie odpowiedzialnych działań (i to w szerokim spektrum: od całkowitego braku zainteresowania problematyką poprzez umiarkowane zainteresowanie nią, aż do stopniowej akceptacji zasad dojrzewającej do pełnej postaci koncepcji - w wyniku czego świadome staje się dążenie do modelu społecznie odpowiedzialnego przedsiębiorstwa).

2. W sytuacji, gdy przedsiębiorca zatrudnia pracowników, a podstawowa działalność oraz warunki organizacyjno-zarządcze temu sprzyjają, wymagane jest zapoznanie personelu z zamiarem metodycznego, systematycznego (lub incydentalnego - w zależności od perspektywy postrzegania kategorii i potrzeb konkretnego przedsiębiorstwa) wprowadzania założeń koncepcji społecznej odpowiedzialności przedsiębiorstwa i planowanymi z tym ewentualnymi zmianami. Przedsiębiorca może wówczas wstępnie zapoznać pracowników z koncepcją, przygotowując plan tematycznych szkoleń. W tym miejscu nie kończy się współpraca z pracownikami: powinni być oni zaangażowani $\mathrm{w}$ cały proces wdrażania i realizacji (docelowo także inni interesariusze).

3. Ocenę przejawów społecznej odpowiedzialności należy poprzedzić kompleksową oceną sytuacji społecznej, organizacyjnej i ekonomicznej przedsiębiorstwa „na wejściu" (najlepiej za pomocą mierników ilościowych i jakościowych).

4. Przejawy społecznej odpowiedzialności powinny być rozeznane na kanwie oceny przez przedsiębiorcę działalności swojego przedsiębiorstwa przez pryzmat odpowiedzialnego działania we wszystkich wymiarach oraz identyfikacji luk oraz potrzeb i możliwości ich zapełnienia.

5. Właściwa identyfikacja istniejących przejawów społecznej odpowiedzialności wymaga od właściciela małego przedsiębiorstwa umiejętności przyporządkowania ich do obszarów: ekonomicznego, prawnego, etycznego, filantropijnego względem interesariuszy wewnętrznych i zewnętrznych odpowiedzialności (podmiotów wewnętrznych: właściciela/właścicieli, menedżera/menedżerów, pracowników i podmiotów zewnętrznych: klientów, dostawców, społeczności lokalnej itd.) oraz rozpoznania potrzeby ich doskonalenia. 
6. Sformułowanie celów głównych i szczegółowych realizacji koncepcji wraz ze sposobami ich monitorowania związane jest $\mathrm{z}$ realizacją funkcji planowania społecznej odpowiedzialności.

7. Kompleksowym działaniem w tym zakresie jest opracowanie lub wybór sposobów pomiaru, raportowania i kształtowania społecznej odpowiedzialności.

8. Przy względnie rozwiniętej realizacji wybranych elementów procesu zarządzania strategicznego, takich jak: posiadanie misji (ewentualnie wizji), celów strategicznych, strategii ogólnej (rzadziej strategii funkcjonalnych), istotne jest uwzględnienie zapisów dotyczących przyjętych założeń koncepcji społecznej odpowiedzialności przedsiębiorstwa: uniwersalnych i szczegółowych zapisów dotyczących wartości i zasad.

9. Preludium do organizowania społecznej odpowiedzialności jest przygotowanie przedsiębiorstwa organizacyjnie (np. zmiany w strukturze organizacyjnej, procedurach, opisach stanowisk itd.) i finansowo (np. wygospodarowanie środków w budżecie itd.).

10. Treścią procesu organizowania powinno być ustawiczne zapewnianie odpowiednich warunków dla realizacji koncepcji związanych m.in. z kształtowaniem w miarę potrzeby struktury organizacyjnej, kultury organizacyjnej, rozwiązań strategicznych, a także integracją w ramach istniejącego systemu zarządzania.

11. Kształtowanie społecznej odpowiedzialności oznacza wdrożenie przygotowanych w procesie planowania konkretnych działań społecznie odpowiedzialnych w ramach obszarów dedykowanych podmiotom przy wykorzystaniu wspomagających koncepcji, metod, sposobów, narzędzi zarządzania.

12. Na podsumowujące cykl zarządzania kontrolowanie społecznej odpowiedzialności w modelowej postaci składają się: pomiar/monitorowanie społecznej odpowiedzialności (ewentualnie raportowanie), analiza i ocena efektów oraz działania korygujące, a także przeprowadzanie usprawnień. Zalecana stopniowość i systematyczność działań w przypadku wdrażania koncepcji ułatwi metodyczne poznawanie i sukcesywne stosowanie poszczególnych, zazwyczaj trudnych, jej elementów.

Szczegółowe wytyczne można podsumować dwoma ogólnymi stwierdzeniami: po pierwsze ważnym elementem implementacji koncepcji jest rozpisanie szczegółowych jej elementów, ich umiejscowienie w rzeczywistości organizacyjnej oraz przyporządkowanie personalne odpowiedzialności za ich przygotowanie, wdrożenie i realizację, po drugie równie ważne staje się ustalenie harmonogramu i zakresu prac (wdrożenie i realizacja) przygotowujących do cyklicznego procesu zarządzania społeczną odpowiedzialnością.

\section{Metodyka badań}

Przedstawione w artykule wnioski sformułowano na podstawie wyników badań literaturowych i empirycznych, będących kontynuacją realizacji projektu badawczego własnego finansowanego przez MNiSW w latach 2010-2012, pt.: Zarządzanie spo- 
łeczną odpowiedzialnością. Identyfikacja - ocena - kierunki doskonalenia. Proces badawczy składał się z kilku etapów: badań wstępnych (lata 2008-2009) i trzech etapów badań właściwych, w czasie których ostatecznie przebadano 187 małych polskich przedsiębiorstw z 12 województw oraz 133 małe przedsiębiorstwa z Irlandii, Wielkiej Brytanii, Niemiec, Czech, Norwegii, Hiszpanii, Włoch. Badania przeprowadzono za pośrednictwem kwestionariuszy ankiety, wywiadu, obserwacji, analizy dokumentacji organizacyjnej, analizy porównawczej na podstawie studium przypadku. Łącznie przebadano 320 przedsiębiorstw. Celem głównym badań była ocena społecznej odpowiedzialności małego przedsiębiorstwa poprzez analizę świadomości przedsiębiorców, identyfikację uwarunkowań, przejawów, sposobów zarządzania społeczną odpowiedzialnością (w tym raportowania) oraz korzyści/kosztów społecznej odpowiedzialności (w perspektywie identyfikacji obszarów i podmiotów społecznej odpowiedzialności, planowania, organizowania, kształtowania i kontrolowania społecznej odpowiedzialności) oraz analizę zarządzania sformalizowanego i niesformalizowanego, a także rozpoznanie, jakie przedsiębiorstwa i kiedy można uznać za odpowiedzialne społecznie. Badania empiryczne oparto na modelowej koncepcji teoretycznej wspartej na zmodyfikowanych modelach A.B. Carrolla, Y.Ch. Kanga i D.J. Wood. K.Davisa i R. Blomstroma, S.L.Warticka i P.L.Corchana oraz na teorii interesariuszy [Sokołowska 2013].

Po ponad czterech latach (lata 2015-2017) od zakończenia badań właściwych w ramach syntetycznie zaprezentowanego projektu badawczego ponownie zbadano szeroko pojęty (osadzony w zaprezentowanych powyżej celach badawczych) stan realizacji koncepcji społecznej odpowiedzialności. Zastosowano zmodyfikowane narzędzia badawcze (kwestionariusze ankiety dla właściciela, pracowników, klientów oraz kwestionariusz wywiadu dla właściciela). Rozbudowane i pogłębione badania empiryczne przeprowadzono na celowo dobranej próbie 48 małych polskich przedsiębiorstw z 12 województw. Celowy dobór przedsiębiorstw związany był bezpośrednio z wynikami badań empirycznych z II etapu badań właściwych z 2011 roku, podczas którego wybrano przedsiębiorstwa pretendujące do miana społecznie odpowiedzialnych, ponieważ wyróżniono w nich cechy, które eksponowały społecznie odpowiedzialny charakter działalności. Proces badawczy trwa.

\section{Wybrane problemy we wdrażaniu koncepcji społecznej odpowiedzialności w małym przedsiębiorstwie}

Zderzenie przedstawionych wcześniej postulatów dotyczących specyfiki wdrażania koncepcji społecznej odpowiedzialności przedsiębiorstwa z wynikami analizy przykładów implementacji pozwala na prezentację następujących kluczowych problemów, do których należy zaliczyć:

- Niedostateczną, szczątkową, wybiórczą wiedzę przedsiębiorców i pracowników na temat koncepcji; zazwyczaj złe skojarzenia dotyczące zarówno samej koncepcji, jak i poszczególnych jej elementów, wynikające z traktowania tego typu 
problematyki w kategoriach „,niepotrzebnego balastu”, „dodatkowego problemu”, ,rozdawania pieniędzy"3 (a jeżeli już istnieje wiedza, to zazwyczaj społeczna odpowiedzialność utożsamiana jest z narzędziem marketingowym). Tylko 12 spośród 48 badanych przedsiębiorców, których wiedza ponownie była zbadana, kojarzyło poprawnie kategorię. Przedsiębiorcy, którzy znali problematykę, zazwyczaj chętnie podejmowali rozmowy (i dalej działania) na temat możliwości kompleksowego, stopniowego wdrożenia założeń koncepcji.

- Asymetrię oczekiwań, zazwyczaj szybkich, od razu widocznych efektów w postaci określonych korzyści i potrzeby przyjęcia długookresowej perspektywy związanej często z organiczną, żmudną pracą, niejednokrotnie nawet ze stratami.

- Wymagające pod względem nakładu pracy przygotowanie zaleceń/procedur dotyczących poszczególnych elementów zarządzania społeczną odpowiedzialnością, które zniechęca przedsiębiorców;

- Niewiązanie różnych obszarów funkcjonowania i elementów zarządzania przedsiębiorstwem z przejawami społecznej odpowiedzialności, pomimo ich identyfikacji w pierwszych etapach badań empirycznych.

- Przenikanie się obszarów odpowiedzialności ekonomicznej, prawnej, etycznej i filantropijnej, co często nastręcza wielu problemów przy ich identyfikacji.

- Brak systematycznej identyfikacji podmiotów społecznej odpowiedzialności interesariuszy wewnętrznych i zewnętrznych, ich podziału na kluczowych i drugorzędnych oraz świadomego kierowania $\mathrm{w}$ ich stronę konkretnych społecznie odpowiedzialnych działań.

- Brak nawyku systematycznego, formalnego planowania w przedsiębiorstwach, znacznie zubażający przejawy planowania społecznej odpowiedzialności (w wielu przedsiębiorstwach nie formułuje się nawet celów ogólnych, nie mówiąc o szczegółowych lub strategicznych i operacyjnych).

- Niedostateczne rozpoznanie (w stosunku do zdiagnozowanych możliwości) przez przedsiębiorców warunków organizacyjnych (struktury i kultury organizacyjnej, ewentualnych rozwiązań strategicznych, specyfiki realizacji funkcji organicznych i procesów itd.) oraz możliwości ich kształtowania w stronę budowania przedsiębiorstwa społecznie odpowiedzialnego.

- Dość skomplikowane propozycje standardów normalizacji, oceny i zarządzania społeczną odpowiedzialnością, które wymagają dostosowania do specyfiki małych przedsiębiorstw (cechuje je nieskomplikowana realizacja funkcji zarządczych, organicznych i procesów).

- Zazwyczaj niskie budżety małych przedsiębiorstw wykluczające stosowanie niektórych narzędzi, zwłaszcza z obszaru ekonomicznego, względem pracowników (np. rozbudowane systemy motywacyjne) lub filantropijnego wobec społeczności lokalnej (np. wsparcie charytatywne, mecenat kultury), itd.

${ }^{3}$ Cytaty pochodzą z wypełnionych kwestionariuszy ankiety dla właściciela. 
Pomimo rozpoznanych w badanych przedsiębiorstwach wielu przejawów społecznej odpowiedzialności i nawet jej częściowej instytucjonalizacji, większość $\mathrm{z}$ nich jest $\mathrm{w}$ bardzo początkowej fazie wdrożeń zasad i instrumentarium koncepcji. $\mathrm{Z}$ wywiadów przeprowadzanych z właścicielami wynika, że generalnie obawiają się oni samodzielnego podejmowania tego typu społecznych inicjatyw, oczekują profesjonalnego wsparcia (ekspertów, doradców, prezentujących dobre i złe praktyki), tym samym zgłaszają wiele wątpliwości i trudności. W związku z tym należy zgłosić bardzo istotny postulat stanowiący, że propozycję rozbudowanych etapów i instrumentów w ramach procesu zarządzania społeczną odpowiedzialnością należy zastępować tzw. szytymi na miarę, zindywidualizowanymi programami dedykowanymi konkretnym przedsiębiorstwom lub ich grupom.

\section{Zakończenie}

Podsumowując, należy stwierdzić, iż poddane badaniom przedsiębiorstwa charakteryzują się zróżnicowanym poziomem implementacji koncepcji i przygotowania do bycia firmą społecznie odpowiedzialną. Procesy wdrażania i realizacji założeń koncepcji przenikają się i uzupełniają, a postawa i dotychczasowe działania przedsiębiorców dobrze rokują, jeśli idzie o możliwości ich pełnego zaistnienia. Jednakże należy mieć także na uwadze fakt, że nawet przy zaproponowaniu zestawu dość prostych procedur (do przedsiębiorców przemawiają nieskomplikowane $\mathrm{w}$ treści i realizacji zasady i instrumenty zarządzania) i próbie modelowania rzeczywistości małych przedsiębiorstw kontekst sytuacyjny sprawia, że jest to grupa wysoce niejednorodna i trudna do jednoznacznej identyfikacji.

Zaprezentowane w artykule rozważania, zważywszy na trwający, kontynuowany proces badawczy, są zaczynem do dyskusji nad badaniem i tworzeniem rekomendacji dla efektywnego zarządzania społeczną odpowiedzialnością oraz wskazują na potrzebę rozłożonej w czasie obserwacji efektów. Ograniczony zakres opracowania nie pozwolił na rozszerzenie listy przedmiotowych problemów oraz wskazanie zidentyfikowanych relacji między przedmiotem, podmiotami badań (właścicielami, pracownikami, wybranymi interesariuszami zewnętrznymi), a także kilkoma zmiennymi przyjętymi $\mathrm{w}$ procesie badawczym (wielkością, przedmiotem działalności, okresem funkcjonowania na rynku itd.). Stopniowego zadośćuczynienia owym brakom należy się spodziewać w kolejnych opracowaniach autorki.

\section{Literatura}

Carroll A.B., 1999, Corporate Social Responsibility - evolution of a definitional construct, Business \& Society, vol. 38, no.3, s. 268-295.

Friedman M., 1970, The social responsibility of business is to increase its increase its profits, New York Times Magazine, September 13 ${ }^{\text {th }}$, vol. 32, no. 33, s.122-124. 
Freeman R.E., Phillips R.A., 2002, Stakeholder theory: Libertarian defense, Business Ethics Quarterly, vol. 12 , no. 3 , s. 331-349.

Garriga E., Mele D., 2004, Corporate Social Responsibility theories: Mapping the territory, Journal of Business Ethics, vol. 8, no. 53, s. 51-71.

Kung H., 1999, Pokój na świecie - światowe religie - światowy etos, [w:] J. Sekuła (red.), Idea etyczności globalnej, Wydawnictwo Seculum, Siedlce.

Madueño H. i in., 2016, Development of corporate social responsibility in small and medium-sized enterprises and its nexus with quality management, Cogent Business \& Management, no. 3, s. 1-21.

Sokołowska A., 2013, Społeczna odpowiedzialność małego przedsiębiorstwa. Identyfikacja - ocenakierunki doskonalenia, Seria: Monografie i Opracowania nr 232, Wydawnictwo Uniwersytetu Ekonomicznego we Wrocławiu, Wrocław.

Sokołowska A., 2016, Uwarunkowania implementacji założeń koncepcji społecznej odpowiedzialności w matym przedsiębiorstwie, Zarządzanie i Finanse, Journal of Management and Finance, vol. 14, nr 2, część 2, s. 351-360. 